\title{
Article
}

\section{An Inspirational Nursing Theorist - Dame Cicely Saunders}

Dobson, Jill

Available at http://clok.uclan.ac.uk/21363/

Dobson, Jill (2017) An Inspirational Nursing Theorist - Dame Cicely Saunders. Cancer Nursing Practice, 16 (7). p. 31. ISSN 1475-4266

It is advisable to refer to the publisher's version if you intend to cite from the work. http://dx.doi.org/10.7748/cnp.2017.e1414

For more information about UCLan's research in this area go to http://www.uclan.ac.uk/researchgroups/ and search for <name of research Group>.

For information about Research generally at UCLan please go to http://www.uclan.ac.uk/research/

All outputs in CLoK are protected by Intellectual Property Rights law, including Copyright law. Copyright, IPR and Moral Rights for the works on this site are retained by the individual authors and/or other copyright owners. Terms and conditions for use of this material are defined in the policies page.

\section{CLoK}

Central Lancashire online Knowledge www.clok.uclan.ac.uk

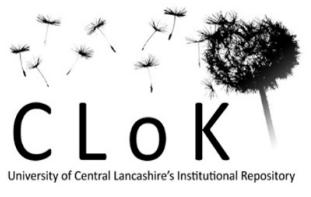




\section{Cancer Nursing Practice \\ An Inspirational Nursing Theorist - Dame Cicely Saunders \\ --Manuscript Draft--}

Manuscript Number:

Article Type:

Full Title:

Corresponding Author:

Abstract:

Keywords:

Additional Information:

Question

Please confirm that you have read and agree to our Publisher's Agreement that is available here

Have you submitted this manuscript elsewhere?

Has this manuscript already been published?

Do you have copyright for all the images, Yes graphics and figures included with your submission?

What is the word count of your document including references but excluding the abstract?

What is the word count of your document excluding both references and the abstract?

\section{Author Comments:}

Yes

No

No
CNP1414R1

Article - if in doubt use this one

An Inspirational Nursing Theorist - Dame Cicely Saunders

Jill Louise Hanslip, MSc Nursing

University of Central Lancashire School of Health Sciences

Preston, Lancashire UNITED KINGDOM

\section{Abstract}

Cicely Saunders isn't well known as being a nursing theorist and is undoubtedly worthier of her recognition as the founder of the modern hospice movement. The theory of 'total pain' bases care of the dying on the whole of the person, treating not just the physical expressions or perceptions of pain but the psychological, social and spiritual. How do other models of nursing for end-of-life care compare to Cicely's Total Pain theory, and can the total pain theory be applied into practice today?

Models of Nursing; Theory Of Nursing; End of Life; Cicely Saunders; Total Pain Theory

\section{Response}

2877

2200

I have read the comments made by both editors \& made changes to the article as much as I can. However, the 2 reviewers were contradictory so it was somewhat difficult to know how to revise the document as best as possible. I have attempted this to the beat of my ability. 


\section{Abstract}

Cicely Saunders isn't well known as being a nursing theorist and is undoubtedly worthier of her recognition as the founder of the modern hospice movement. The theory of 'total pain' bases care of the dying on the whole of the person, treating not just the physical expressions or perceptions of pain but the psychological, social and spiritual. How do other models of nursing for end-of-life care compare to Cicely's Total Pain theory, and can the total pain theory be applied into practice today?

\section{Introduction}

Before the formation of the hospice movement, historically, people died in their own homes, cared for by their family and loved ones (Broom \& Cavenagh, 2010). The definition of the term "hospice" is a house of rest and entertainment for pilgrims, travellers, or strangers, one belonging to a religious order, as those of the monks of St. Bernard and St. Gotthard on the Alps; also, generally, a 'home' for the destitute or the sick (Oxford English Dictionary, 2014).

The title 'hospice' was first associated to dedicated care for dying patients by Dame Cicely Saunders, who began her work with the terminally ill in 1948 and eventually went on to create the first modern hospice (Oransky, 2005). Palliative medicine has a brief history, but a crucial one in which Britain plays an immensely significant role (Baines, 2011). According to Twycross (1977), Hospice palliative care was primarily a remonstration against medical negligence in the post-war years when medicine began to advance into the specialty it is currently. As doctors had more they could do for the living, then the dying became more neglected. It now seems significant that the discipline did not exist earlier than the late 1980 s which was due to the unfortunate fact that physicians who now concentrated on treatment and cure, found the dying patient as a failure where medical involvement was no longer required; unable to cure - so unable to care (Du Boulay, 2007). 


\section{Cicely Saunders}

Dame Cicely was born in 1918 in Hertfordshire and came from a wealthy background where her parents discouraged her to study nursing and instead she went to Oxford to study Politics,

Philosophy and economics. She performed well in her studies until World War 2 broke out in 1939 and Cicely knew she had to do something more useful and practical. She enrolled at St. Thomas's for nurse training; ignoring her parent's advice (Du Boulay, 1985).

Cicely trained as a nurse 1940-1944 at St. Thomas's School of Nursing and then went on to train as a medical social worker in 1947. Whilst working in a Royal cancer hospital, Cicely met and fell in love with David Tasma, a cancer patient and through his encounters she recognised that terminally ill patients needed improved care. Cicely revealed her vision with David and upon his death, he bequeathed $£ 500$ to Cicely which became her inspiration for fulfilling her dream (Du Boulay, 1985). Cicely went on to train as a doctor in 1951-1957; following graduation as a physician, she studied pharmacology to understand how to alleviate pain in the terminally ill; she promoted the regular administration of pain medication rather than being waiting to be asked for it (Du Boulay, 1985). The current practice at this time, was to only administer pain relief when pain was agonising, as it was feared the terminally ill would become addicted to the pain medication! Many dying patients were in severe pain and were given the 'Brompton Cocktail' which included the ingredients:

- $\quad$ nepenthe or liquor morphini hydrochloride

- cocaine hydrochloride

- tincture of cannabis

- $\operatorname{gin}$

- $\quad$ syrup

- chloroform water, Richardson and Baker (1956) cited in Clark (2014), 
which rendered patients to a state where they didn't know what was happening (Seymour 2012).

Cicely researched and advocated that there was little evidence of this addiction occurrence and that lower dosage given at regular intervals allowed patients' pain to be controlled and patients to remain alert. Saunders, along with her colleague Twycross, convinced others that the Brompton cocktail should be substituted with Morphine regularly instead of when it is asked for (Meldrum, 2005 cited in Seymor, 2012). Twycross went on to transform Cicely's Total Pain theory, in inspiring the internationally approved standards for the relief of pain for those suffering with cancer formed in the 1980's by the World Health Organisation: The Three Step Ladder, and the first definition of palliative care reflects Cicely's Theory and Framework, (Meldrum, 2005 cited in Seymor, 2012). This is the protocol still used in palliative practice today (Oransky, 2005). Cicely made her plans for a hospice, her vision being that it would provide not only physical care but also spiritual and emotional care that would be comforting with a home-like atmosphere. The hospice would also encompass the care of patients' families and their loved ones. St. Christopher's was founded in 1967, and was given the name by one of her patients who she had cared for and shared her vision for the hospice; it was the first facility in the world created for caring for the terminally ill and training those caring for terminally ill patients (Du Boulay, 1985). Another of Cicely's great achievements is banishing the primitive notion held that care of the dying was unimportant and raising the profile of palliative care as a medical speciality within its own right; end of life 'specialism' instead of 'generalism' (Oransky, 2005).

\section{Theory of total pain}

Cicely's objective was to alleviate pain for the terminally ill, however it presented itself, and it wasn't long before Cicely realised that pain was more than just physical. Cicely developed and instituted the concept and theory of care for the whole person, providing dignity and comfort until the end of life. Cicely formulated the theory and term 'Total pain' which demonstrates the multifaceted nature of the palliative patient's pain experience which includes physical, psychological, social and spiritual. 
Pain is one of the most frequent and troubling symptoms for palliative care patients and their loved ones (Stjernsward et al, 1996; Breitbart, 1989), and unfortunately is a symptom and experience that is inevitable for many of those at the end of life (Mehta \& Chan, 2008).

Pain is a subjective experience (Saunders, 1993, McCaffery, 1979 cited in Mehta \& Chan, 2008), the failure to vocalise or demonstrate a pain experience, does not refute the necessity for pain relieving management. The assessment of pain is a crucial part of nursing management of symptom control at the end of life and understanding that patient's experience of 'total pain' is critical and nurses should empathise that patients pain experience may be other than that of physical, exploring all possible influences and potential causes (Mehta \& Chan, 2008). By treating the whole person rather than just the physical pain, Cicely found that actual pain was often reduced, that if a patient felt that they were heard and understood, there were diminishing drug requirements (Du Boulay, 2007).

\section{Cicely Saunders: Theory in practice today}

The theory and framework of Total pain is not treating the dying patient and their pain alone and the framework must be seen and used as a holistic framework in the care of the patient as a whole, not only when assessing or when a patient is suffering with pain; but each patient will be treated from a physical, psychological, social and spiritual perspective and not the physical alone. Although the theory of 'Total pain' has been discussed as a major part of Cicely Saunders contributions to Palliative care nursing and medicine, her most notable attainment throughout history is the recognition of care of the dying as an important role within the context of healthcare as a whole, ensuring that palliative and end of life care has become a speciality within its own right. Cicely believed that a society that neglected the dying, had an incomplete philosophy and she aimed to change that, and she did, not just in one country but all over the world. Her theory and ideas continue within palliative care and in mainstream medicine today (Du Boulay, 2007). It is evident in many policies and guidance in recent years, especially since the Francis report (2013), that patients should be treated holistically and Cicely's framework is apparent yet again in the more recently 
published end-of-life guidance: 'One chance to get it right' (Leadership Alliance for the Dying Patient 2014), that mentions the treatment of dying patients from a physical, psychological (emotional), social and spiritual perspective and that the needs of family and loved ones (those who are important) should be met as much as possible. This is evidence of Cicely's philosophy and principles of her theory existing in policy being published for care of the dying today, some 50 years since its creation.

\section{Nursing models and theories}

The theory and practice of nursing in the past has been shaped and determined by the aims of medicine (Pearson 1996 cited in Murphy 2010). Anxieties between nurses about the appropriateness of the medical model added motivation to the development of models and theories for nursing (Pearson et al, 1996). Ida Jean Orlando introduced the first concept of the nursing process in the 1950s when she observed nurses in action. What she learned was they performed 'good' nursing \& 'bad' nursing (Quan 2013). The four-stage problem solving process, which was not endorsed in the UK until the 1970s, aimed to improve the provision of care to an individual and was an important tool in applying nursing theory into practice (Aggleton and Chalmers 1986 cited in Murphy 2010). The principles, ideals and theories for care within a model could be used to direct the assessment, planning, implementation and evaluation of care.

Models of nursing signify a key stage in the growth of nursing theory and nursing as a discipline. Nursing models were intended to embody the values and beliefs held by unique authors such as Orlando. The irony is that one of the central drives of designing nursing models was to encapsulate and convey the character and contribution of nursing as a discipline. However, Miller (1984) cited in Murphy (2010) argues that models are sometimes overstated, lacking bearing to the reality of nursing and, as such, they increase the disparity between theory and practice. This is a valid point and many models cannot be applied to every area of practice and can appear too complex to be interpreted which Murphy (2010) agrees, stating Orem's model of nursing uses complicated
Commented [A4]: Amended sub-heading in reference to comments from revision.

Commented [A5]: Added text in regards to comments on revision.

Commented [A6]: Word added. 
terminology which confuses the user and can potentially deter nurses from its application in practice.

\section{End of Life Models - How do they compare to Total Pain Theory?}

In relation to end of life models of care and those that could be related to Cicely Saunders Total Pain Theory, one model which saw some equivalent themes was the Respectful Death Model, which is a holistic, practical model developed to enhance end-of-life care. A respectful death is one which supports dying patients, their families, and professionals in the close of life cycles and can be used by all members of the healthcare team. The model is a process method starting with the formation of a therapeutic rapport with the dying patient and his or her family and, as a result, their stories are heard and combined into the care plan (Wasserman 2008). This model is comparative to that of Cicely's vision as it encompasses the community concept of incorporating a holistic approach to care of the dying.

Another theorist which shares precise findings to Saunders is Jean Watson with her developing theory of nursing as a caring science, a sacred science. Watson's (1979) cited in Mullaney (2000) theory, ordering of needs encompasses meeting those needs of: physical, social, spiritual and psychological which are itemised in order of need.

These orders of needs can be very closely related to Maslow's hierarchy of needs (1943) who stated that people are motivated to accomplish specific essentials. When one need is satisfied, a person seeks to fulfil the next one, and so on (McLeod 2007). It appears that these models are all interlinked with each other which indicates that when caring, theorist's share comparable findings.

Katherine Kolcaba's comfort theory (1994 cited in March \& McCormack 2009), describes comfort as prevailing in 3 forms: relief, ease, and transcendence. If certain comfort requirements of a patient are met, the relief of pain from prescribed analgesia, the patient encounters comfort in the alleviation sense; how an individual feels following having issues that were causing anxiety
Commented [A7]: Sub-heading added in response to revision comments to add clarity \& flow. 
addressed. Lastly, transcendence is explained as the state of comfort where patients are able to rise and climb above challenges. Again, showing similar concepts to Saunders theory and vision, contexts of comfort, Kolcaba described 4 contexts in which patient comfort can occur: physical, psychospiritual, environmental, and sociocultural. (March \& McCormack 2009).

\section{$\underline{\text { Recommendations for practice }}$}

All nursing models have their place in practice to guide nursing practice and to enhance care where utilised in the context of the appropriate environment. It is fair to say that there is no single model or theory that can be used universally, instead, elements from various relevant models may benefit the individual patient suitably and individualised care planning being appropriate.

In consideration of Dame Cicely Saunders Total Pain Theory and how it is comparable to resembling models of nursing care, it is clear to see that despite this theory being devised in 1960's, the theory is unconsciously still being utilised within end-of-life care and within the newly published guidance 'One chance to get it right' (LACDP 2014) for the care of all dying adults. Although Saunders has not received recognition for this, it is clear that the principles are there and if the philosophy of the total pain theory is embedded within the new guidance and this ensures high quality end-of-life care, then surely Cicely Saunders would be proud.

Commented [A8]: Word changed in response to revision comments 


\section{$\underline{\text { References }}$}

Aggleton and Chalmers (1986). In Murphy, F. (2010). Nursing models and contemporary nursing 1: their development, uses and limitations. Nursing Times. 106 (23).

Baines M (2011) From pioneer days to implementation: lessons to be learnt. European Journal of Palliative Care. 18 (5), 223-227.

Breitbart W (1989) Psychiatric management of cancer pain. Cancer. 63 (1), 2336-2342.

Broom A \& Cavenagh J (2010) Moralities, masculinities and caring for the dying: An exploration of experiences of living and dying in a hospice, Social science and medicine. 71 (5), 869-76.

Du Boulay S (1985) Changing the face of death: the story of cicely saunders. Exeter: BPC Wheatons Ltd.

Du Boulay S (2007) Cicely saunders: the founder of the modern hospice movement. Great Britain:

Ashford colour press.

Kolcaba KY (1994) A theory of holistic comfort for nursing. Journal of advanced nursing; 19, 1178-

1184.

Leadership Alliance for the Care of Dying People (2014) 'One Chance to get it right'. Improving people's experience of care in the last few days and hours of life: Leadership Alliance for the Care of Dying People

March A \& McCormack D (2009) Nursing theory-directed healthcare modifying Kolcaba's comfort theory as an institution-wide approach. Holistic nursing practice March/April 2000.

McCaffery (1979) Cited in Mehta A \& Chan LS (2008) Understanding the concept of 'total pain': a prerequisite for pain control. Journal of hospice and palliative nursing. 10 (1), 26-32.

McLeod S (2007) Simply psychology. Accessed at : http://www.simplypsychology.org/maslow.html 
Mehta A \& Chan LS (2008) Understanding the concept of 'total pain': a prerequisite for pain control. Journal of hospice and palliative nursing. 10 (1), 26-32.

Meldrum (2005) cited in Seymor J (2012) Looking back, looking forward: the evolution of palliative care and end-of-life care in England. Mortality. 12 (1), 1-13.

Miller (1984) cited in Murphy F (2010). Nursing models and contemporary nursing 1: their development, uses and limitations. Nursing Times. 106 (23), 18-20.

Mullaney JAB (2000) The lived experience of using Watson's actual caring occasions to treat depressed women. Journal of Holistic Nursing. 18 (2), 129-142.

Murphy F (2010). Nursing models and contemporary nursing 1: their development, uses and limitations. Nursing Times. 106 (Richardson J S \& Baker D (1956) The Management of Terminal Disease. In the Practice of Medicine. London: Churchill. Cited in Clark, D. (2014). The Brompton Cocktail: 19th century origins to 20th century demise-Retrieved from: http://endoflifestudies.academicblogs.co.uk/the-brompton-cocktail-19th-century-origins-to20th-century-demise/

23), 18-20.

Oransky I (2005) Dame Cicely Mary Strode Saunders, The Lancet. 366 (9486), 628.

Oxford English Dictionary (2014) Accessed at: http://www.oed.com/

Pearson (1996) Cited in Murphy F (2010) Nursing models and contemporary nursing 1: their development, uses and limitations. Nursing Times. 106 (23), 18-20.

Quan K (2013) The Nursing Site, Nurses are Masters at the Fine Art of Caring. Accessed at: www.thenursingsite.com/historyofnursing/code/impactonnursing.htm

Saunders C (1993) Introduction: history and challenge. Cited in Sykes N (Eds.), The management of terminal malignant disease (pp1-14). London, Great Britain: Hodder \& Stoughton. 
Seymor J (2012) Looking back, looking forward: the evolution of palliative care and end-of-life care in England. Mortality, 12 (1), 1-13.

Stjernsward J Colleau SM \& Ventafridda V (1996) The World Health Organisation cancer pain and palliative care program: Past, present and future. New York: WHO Collaborating centre for symptom evaluation.

Twycross RG (1977) Choice of strong analgesic in terminal cancer: diamorphine or morphine? Pain. 3 (93-104).

Wasserman LS (2008) Respectful death: a model for end-of-life care. Clinical journal of oncology nursing. 12 (4), 621-626. doi: 10.1188/08.CJON.621-626.

World Health Organisation (1990) Cited in Seymor J (2012) Looking back, looking forward: the evolution of palliative care and end-of-life care in England. Mortality, 12 (1) 1-13. 